ESJ Social Sciences

\title{
The Effects of the Covid-19 Pandemic on Kuwaiti Kindergarten Staff to Adopt E-Learning System
}

\author{
Alia Ashkanani, (PhD) \\ Ministry of Education, Kuwait \\ Abdalmonem Tamtam, (PhD) \\ Dublin City University, Ireland, Nalut University, Libya,
}

Doi:10.19044/esj.2021.v17n12p59

Submitted: 17 March 2021

Accepted: 21 April 2021

Published: 30 April 2021
Copyright 2021 Author(s)

Under Creative Commons BY-NC-ND

4.0 OPEN ACCESS

Cite As:

Ashkanani, A. and Tamtam, A. (2021). The Effects of the Covid-19 Pandemic on Kuwaiti Kindergarten Staff to Adopt E-Learning System. European Scientific Journal, ESJ, 17(12), 1.https://doi.org/10.19044/esj.2021.v17n12p59

\section{Abstract}

E-learning has been implemented on a mass scale during the COVID19 crisis although many schools faced huge problems during the system implementation and roll-out.

This paper has used the technology acceptance model (TAM) to investigate the teachers and administrative staff's prospective on the use of e-learning in the education process. The study has implemented a quantitative method to collect data through a questionnaire. The study had 204 participants which included teachers and administrative staff in kindergartens under the Kuwaiti Ministry of Education (MOE).

The study showed that the majority of the participants were not in favor of elearning as the system was neither clear nor it was understandable or flexible, which hindered teachers work. The Ministry of educations strategy to bring e-learning to the mass users was undermined due to unclear strategic objective and lack of proper training and support that stood as a barrier to users' acceptance of e-learning. 
Keywords: Technology Acceptance Model (TAM), E-learning, Technical Support, Training, Computer Self-efficacy, Organization Strategy Focus

\section{Introduction}

In 2020 the Ministry of Education (MOE) in the State of Kuwait has introduced e-learning at all levels of schooling in order to provide the necessary education during the Covid-19 crisis. E-learning in Kindergartens has never seen possible until this time of crisis. This is due to the fact that learning at kindergarten level has always been driven by physical movement of the teachers and the children, which makes learning attractive and less stressful to little children. On the other hand, e-learning would be considered a challenge since it would have to overcome the effect of physical separation between teachers and students while maintaining the attractiveness of learning. In 2020 the Ministry of Education (MOE) in the State of Kuwait has introduced e-learning at all levels of schooling in order to provide the necessary education during the Covid-19 crisis. E-learning in Kindergartens has never seen possible until this time of crisis. This is due to the fact that learning at kindergarten level has always been driven by physical movement of the teachers and the children, which makes learning attractive and less stressful to little children. On the other hand, e-learning would be considered a challenge since it would have to overcome the effect of physical separation between teachers and students while maintaining the attractiveness of learning.

Many studies have focused on the impact of today's technology on children. Technology is accused of shattering the foundation of family's social life and causing the breakup of human core values (Rowan, 2017). A 2010 Kaiser Foundation study showed that elementary aged children use on average 7.5 hours of entertainment technology per day, which among other technology related habits, are argued they may lead to children entering school with a tendency to struggle with self-regulation and attention skills required for learning.

On the other hand, others argue that children interaction with technology is important because it prepare them for the foreseen work environment and future modern life. Therefore, this study draws on the importance of subjecting kindergartens to e-learning based on the following points:

- E-learning is considered the formal technology utilization in education. Therefore, it is important to explore the application of e-learning and the extension of how such technology would meet the educational targets. 
- $\quad$ Children exposure to technology in various setting such as education, a part of the others such as entertainment and social media, should always be under scholars focus.

- $\quad$ The application of e-learning at kindergartens level is considered crucial due to children age when exposed to technology, which is considered important to study.

\subsection{Study Questions:}

This paper investigates the impact of the factors Computer SelfEfficacy, System Quality, Technical Support, and Professional Development, on the two core beliefs that formulate a school staff's attitude toward elearning and their behavioral intention to use the system, Perceived Usefulness (PU) and Perceived Ease of Use (PEOU) of the e-learning system. In order to find out the answers to these questions the Technology Acceptance Model (TAM) (Davis, 1986) has been applied for this study.

\section{Related Works:}

The success of e-learning application depends on the behaviour and attitude of the people involved in the education process and their acceptance of such technology. Hence, TAM has always been considered a robust model to be applied in such studies.

It is important to focus on the external parameters that effect how people would handle technological implementation and the extension of its success.

- One of the most important aspects when it comes to implementing technology-based projects, the organization management approach is considered crucial in succeeding on meeting the aimed objectives. Therefore, this study has focused on the following parameters:

\subsection{Computer Self-Efficacy:}

According to Bandura \& Wood (1989), Self-efficacy (SE) is one's belief in his/her capability to mobilize the motivation and cognitive resources necessary to meet given situational demands. The concept of self-efficacy has received attention from the organizational behaviour literature. Thus, recognition of self-efficacy reflects an important aspect in implementing computer-based systems effectively. Hence, it is essential to have a reliable measurement of SE (Compeau \& Higgins, 1995).

On the other hand, Computer Self-Efficacy (CSE) is the ability of the individual's self-assessment to apply computer skill to achieve their tasks (Compeau \& Higgins, 1995). CSE has three effects on individuals, namely, the product of their computer use, their emotional reaction toward 
computers, and the degree of actual utilization of computers in their work. Several empirical studies found significant effects of CSE on the Perceived Usefulness (PU) and Perceived Ease of Use (PEOU) of an e-learning system (Ferdousi, 2009; Waheed \& Farooq Hussain, 2010; Gong, et al., 2004). CSE's main effect is found on PEOU, because it is recognized that, the higher the core competence in the use of computers, the easier the system will appear to the system user. Therefore, it is an important construct that affects teachers' perspective towards their use of e-learning systems. Kuwait's Ministry of education invested in ICT, prior to implementing an elearning system, so there was a spread of computer utilization among the people involved in the education process beforehand.

\subsection{Professional Development:}

There are several studies that explored Professional Development (PD) within the framework that focused on producing theory-based concepts for better programme design and content dissemination (Dede \& Ketelhut, 2009). However, there are limited theoretical and empirical studies on PD as a factor that influences the teacher's perspectives toward using a new elearning system. One study by Kopcha (2012) views PD as being an important supporting factor to integrate teachers within the environment created by the new technology. Moreover, other studies emphasize that developing teachers, by training and upgrading their technological knowledge and skills, is essential to their acceptance of e-learning systems in teaching practices (Al-Senaidi, et al., 2009). Teachers need to attend training sessions or other forms of development to meet the demands of teaching with e-learning systems. Therefore, there is a need to make institutional administrations aware that teachers need to develop their skills to use elearning systems (Greer, 2002), otherwise, the absence of clear training and learning policies with intention to develop staff knowledge and skills will become a barrier to e-learning implementation (Alkharang \& Ghinea, 2013).

\subsection{Technical Support:}

Technical Support (TS) is one of the most important factors that have a direct effect on PU and PEOU, which affects the users' attitudes towards the e-learning system (Ngai, et al., 2007). According to Ralph (1991), TS is represented by organization staffs that have adequate knowledge to assist system users with computer hardware and software problems. Such support can include online support help desks, hotlines, services, machine-readable support knowledge base, faxes, automated telephone voice response systems, remote control software, and other facilities. Although the MOE in the State of Kuwait has incorporated technical support from its own resources and 
from Kuwait University in order to ensure smooth implementation of elearning in Kuwait schools, the support provided has never been studied from the perspective of their contribution in shaping teachers' beliefs on elearning at respective schools. Therefore, TS is considered one of the external factors in the study's theoretical model.

\subsection{Organization Strategic Focus:}

Based on Kuwait society public opinion, the successful implementation of e-learning technology in Kuwait schools appeared to become an important factor in measuring the MOE success in meeting their educational targets. To focus on the role of technology, Van Der Wende and Van De Ven (2003) argue that it is one of the main external drivers for change, beside demography, governmental policy, and economic factors. Therefore, the development of Organization Strategic Focus (OSF) is a vital ingredient in the implementation plan for any technology driven initiative in educational institutes.

When seeking to define the concept Mintzberg, (1987) argued that "it requires not one, but five particular definitions of strategy; a plan, a ploy, a pattern, a position and a perspective". On the organizational management level, he cited Glueck's (1980, p. 9) definition as "a unified, comprehensive and integrated plan ... designed to ensure that the basic objectives of the enterprise are achieved". Strategy is often confused with the term 'Policy', which is defined as "the set of basic principles and associated guidelines, formulated and enforced by the governing body of an organization, to direct and limit its actions in pursuit of long-term goals" (Business_Dictionary, 2016). In the context of this study, organization strategy would be the higher plan used to reach the strategic goals, while the policy would take a subsidiary position; a set of guiding procedures that help the assigned entity within the organization in its decision-making process.

Educational institutes have to evolve their strategies in adding e-learning in their educational delivery and support processes. Education organizations have to strategically plan the "learning implementation processes in order for it to be successful. Bates (2008) listed several steps to encourage the use of technology in teaching:

- Identify new target groups that could be reached using technology.

- Define priority target groups and appropriate programs for the use of technology-based delivery.

- Identify areas of already-existing technology support and encourage people in those areas to provide support for "novice" technology users. 
- Identify areas of support outside the department, faculty, or institution. Meanwhile, determine the organizational support staffing for technology-based teaching, if still required in-house.

- $\quad$ Ensure that innovation and the skilled use of technology is properly recognized and rewarded.

- Identify the priorities for face-to-face teaching, in case technologybased learning is successful in meeting the targets.

- Decide on key areas of investment and resource allocation for technology-based teaching.

It is essential to investigate the impact of clear OSF on teachers' perspectives toward the use of an e-learning system at the organization level. In other words, the study seeks to examine the impact of OSF on the teachers' beliefs with respect to e-learning system, and their intention to use it, in terms of planning and in the setting of policies.

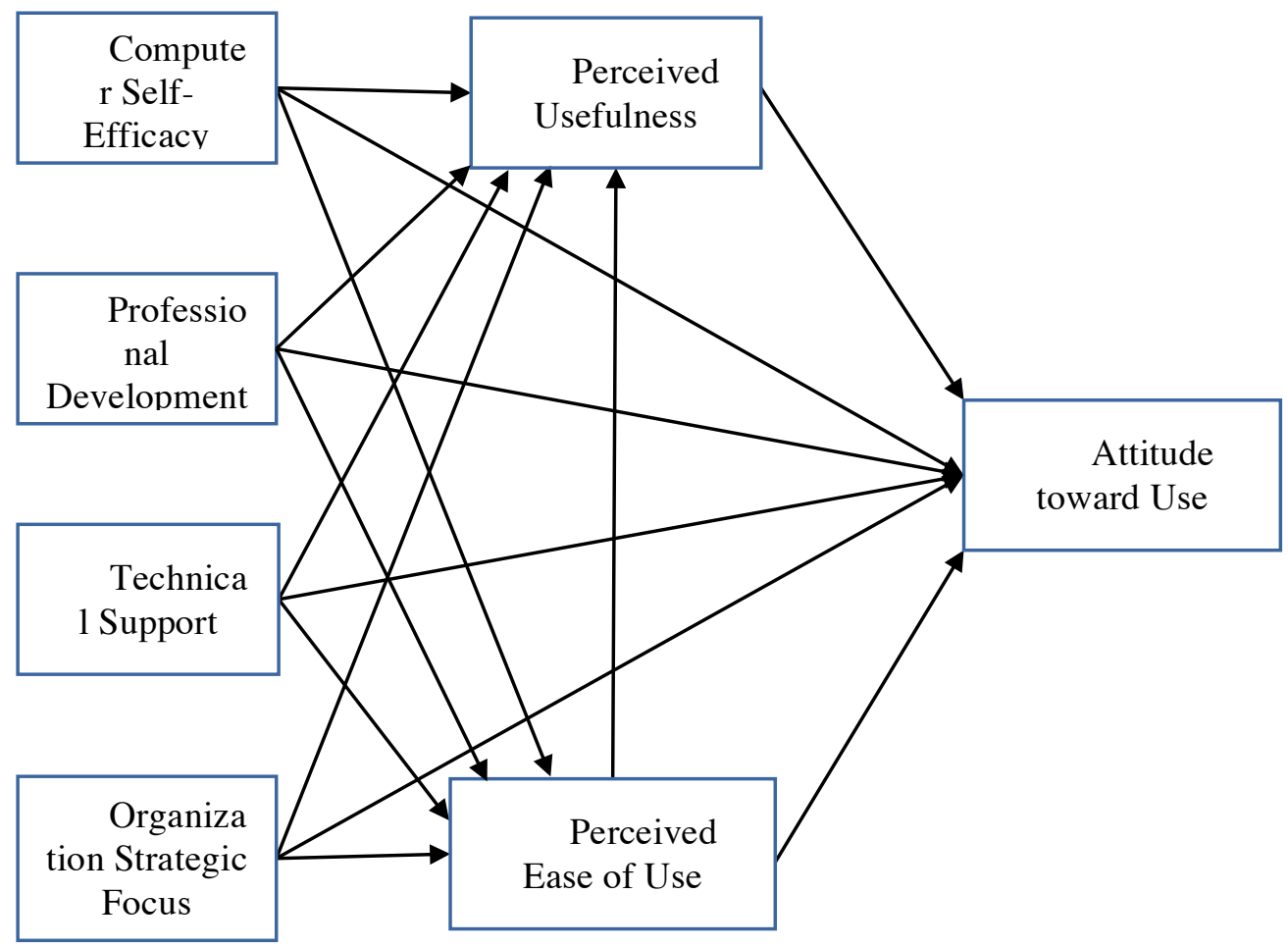

\section{Methods:}

Figure 1: The Study Model

The Technology Acceptance Model (TAM) is incorporated in the study model (Figure 1). The study population was around 530 teachers and administrative staff from Kindergarten schools in Hawalli Province part of the State of Kuwait. A total number of 204 people participated in the survey for this study, the questionnaire was accessed using an electronic web-link 
(https://qfreeaccountssjc1.azl.qualtrics.com/jfe/form/SV_22YcjwQWoeSkw $\mathrm{Hb}$ ), generated in the survey web-site www.Qualtrics.com and distributed using "What's up" mobile application. The study implemented a quantitative method to collect data through a questionnaire. A total of $22(10.8 \%)$ were administrative and support staff and $182(89.2 \%)$ were teachers. Data was analyzed using SPSS software version 27. The survey used a five-point Likert scale with "SD = Strongly Disagree, $\mathrm{D}=$ Disagree, $\mathrm{N}=$ Neutral, $\mathrm{A}=$ Agree and SA = Strongly Agree ".

\section{Findings:}

The main analysis will provide answers to the research questions that guide this study. The research questions were, "What is the impact of the factors Computer Self-Efficacy, Technical Support, and Professional Development and Organization Strategic Focus on the two core beliefs that formulate a school staff's attitude toward e-learning and their behavioral intention to use the system.

\subsection{Demographic information:}

The table below shows the distribution of demographic information, job role, age group, years of experience and children level.

Table 1: Frequencies of demographic information

\begin{tabular}{|l|c|l|l}
\hline \multicolumn{2}{|c|}{ Demographic factor } & Frequency & Percent \\
\hline Job Role & Teachers & 182 & $89.2 \%$ \\
\cline { 2 - 4 } & $\begin{array}{c}\text { Administration and } \\
\text { Support staff }\end{array}$ & 22 & $10.8 \%$ \\
\hline \multirow{4}{*}{ Age Group } & 36 and Below & 133 & $65.5 \%$ \\
\cline { 2 - 4 } & $37-42$ & 45 & $22.2 \%$ \\
\cline { 2 - 4 } & $43-49$ & 17 & $8.4 \%$ \\
\hline \multirow{3}{*}{$\begin{array}{l}\text { Years of } \\
\text { Experience }\end{array}$} & 50 and above & 8 & $3.9 \%$ \\
\cline { 2 - 4 } & 1 to 5 years & 32 & $32.8 \%$ \\
\cline { 2 - 4 } & 6 to 11 years & 67 & $28.4 \%$ \\
\cline { 2 - 4 } & 12 to 15 years & 58 & $23.0 \%$ \\
\hline
\end{tabular}




\subsection{Descriptive Analysis:}

\subsubsection{Computer Efficacy}

The results of the descriptive statistics to each item of the Computer Efficacy are presented in table 2 .

Table 2: Frequencies and Distributions of Respondents on Computer Efficacy

\begin{tabular}{|c|c|c|c|c|c|c|c|}
\hline \multicolumn{2}{|c|}{ Item } & SD & D & $\mathrm{N}$ & $\mathrm{A}$ & SA & Total \\
\hline \multirow[b]{2}{*}{01} & $\mathrm{n}$ & 35 & 38 & 45 & 51 & 35 & 204 \\
\hline & $\%$ & $17.2 \%$ & $18.6 \%$ & $22.1 \%$ & $25.0 \%$ & $17.2 \%$ & $100.0 \%$ \\
\hline \multirow[b]{2}{*}{02} & $\mathrm{n}$ & 37 & 36 & 50 & 54 & 27 & 204 \\
\hline & $\%$ & $18.1 \%$ & $17.6 \%$ & $24.5 \%$ & $26.5 \%$ & $13.2 \%$ & $100.0 \%$ \\
\hline \multirow[b]{2}{*}{03} & $\mathrm{n}$ & 44 & 33 & 45 & 57 & 25 & 204 \\
\hline & $\%$ & $21.6 \%$ & $16.2 \%$ & $22.1 \%$ & $27.9 \%$ & $12.3 \%$ & $100.0 \%$ \\
\hline
\end{tabular}

On item 01, which stated, "I can do my work on E-learning system if I see someone else do it" more than one-third (35.8\%) either disagreed or strongly disagreed with the statement, while $(42.2 \%)$ either agreed or strongly agreed with it and relatively small number $(22.1 \%)$ indicating neutrality.

On item 02, which stated, "I could do my work on E-learning if I used similar system before" more than one-third (35.7\%) either disagreed or strongly disagreed with the statement, while (39.7\%) either agreed or strongly agreed with it and mostly one-fourth $(24.5 \%)$ indicating neutrality. On item 03, which stated, "I can do my work on E-learning if I have instruction manual" (37.8\%) either disagreed or strongly disagreed with the statement, while an almost equal number (40.2\%) either agreed or strongly agreed with it, while less than one-sixth $(22.1 \%)$ indicating neutrality.

\subsubsection{Professional Development}

The results of descriptive statistics to each item of Job Training for professional development are presented in table 3.

Table 3: Frequencies and Distributions of Respondents on Job Training

\begin{tabular}{|c|c|c|c|c|c|c|c|}
\hline \multicolumn{2}{|c|}{ Item } & SD & D & $\mathrm{N}$ & A & SA & Total \\
\hline \multirow[b]{2}{*}{01} & $\mathrm{n}$ & 62 & 53 & 32 & 34 & 23 & 204 \\
\hline & $\%$ & $30.4 \%$ & $26.0 \%$ & $15.7 \%$ & $16.7 \%$ & $11.3 \%$ & $100.0 \%$ \\
\hline \multirow[b]{2}{*}{02} & $\mathrm{n}$ & 91 & 43 & 22 & 26 & 22 & 204 \\
\hline & $\%$ & $44.6 \%$ & $21.1 \%$ & $10.8 \%$ & $12.7 \%$ & $10.8 \%$ & $100.0 \%$ \\
\hline \multirow[b]{2}{*}{03} & $\mathrm{n}$ & 72 & 50 & 38 & 27 & 17 & 204 \\
\hline & $\%$ & $35.3 \%$ & $24.5 \%$ & $18.6 \%$ & $13.2 \%$ & $8.3 \%$ & $100.0 \%$ \\
\hline
\end{tabular}


On item 01, which stated, "I can use the training I received in all my classes" a majority (56.4\%) either disagreed or strongly disagreed with the statement, while almost one-third (30.0\%) either agreed or strongly agreed with it and one-sixth $(15.7 \%)$ indicating neutrality.

On item 02, which stated, "I feel I got adequate training on Elearning system" a large majority (65.7\%) either disagreed or strongly disagreed with the statement, while third number $(33.5 \%)$ either agreed or strongly agreed with it and only $(10.8 \%)$ indicating neutrality.

On item 03, which stated, "I had good chance to share technology with others" majority of the participants (59.8\%) either disagreed or strongly disagreed with the statement, while a small number (21.5\%) either agreed or strongly agreed with it, while less than one-fifth (18.6\%) indicating neutrality.

\subsubsection{Technical Support}

The results of descriptive statistics to each item for Technical Support are presented in Table 4.

Table 4: Frequencies and Distributions of Respondents on Technical Support Policy

\begin{tabular}{|c|c|c|c|c|c|c|c|}
\hline \multicolumn{2}{|c|}{ Item } & SD & D & $\mathrm{N}$ & A & SA & Total \\
\hline \multirow[b]{2}{*}{01} & $\mathrm{n}$ & 57 & 34 & 56 & 37 & 20 & 204 \\
\hline & $\%$ & $27.9 \%$ & $16.7 \%$ & $27.5 \%$ & $18.1 \%$ & $9.8 \%$ & $100.0 \%$ \\
\hline \multirow[b]{2}{*}{02} & $\mathrm{n}$ & 56 & 36 & 63 & 30 & 19 & 204 \\
\hline & $\%$ & $27.5 \%$ & $17.6 \%$ & $30.9 \%$ & $14.7 \%$ & $9.3 \%$ & $100.0 \%$ \\
\hline & $\mathrm{n}$ & 58 & 35 & 55 & 36 & 20 & 204 \\
\hline 03 & $\%$ & $28.4 \%$ & $17.2 \%$ & $27.0 \%$ & $17.6 \%$ & $9.8 \%$ & $100.0 \%$ \\
\hline
\end{tabular}

On item 01, which stated, "Technical support provided by MOE improve my work" a majority (44.6\%) either disagreed or strongly disagreed with the statement, while less than one-third (27.9\%) either agreed or strongly agreed with it and less than one-third (27.5\%) indicating neutrality. On item 02 , which stated, "Technical support improve my productivity" a majority (45.1\%) either disagreed or strongly disagreed with the statement, while less than one-fourth $(24.0 \%)$ either agreed or strongly agreed with it and less than one-third (30.9\%) indicating neutrality.

On item 03, which stated, "Technical support makes E-learning system more effective" a majority (45.6\%) either disagreed or strongly disagreed with the statement, while less than one-third (27.4\%) either agreed or strongly agreed with it with mostly same number $(27.0 \%)$ indicating neutrality. 


\subsubsection{Organization Strategic Focus}

The results of the descriptive statistics to each item of the Ministry of Education (MOE) Organizational Strategic Focus (OSF) are presented in table 5.

Table 5: Frequencies and Distributions of Respondents on Ministry of Education (MOE) Strategic Planning

\begin{tabular}{|c|c|c|c|c|c|c|c|}
\hline \multicolumn{2}{|c|}{ Item } & SD & D & $\mathrm{N}$ & $\mathrm{A}$ & SA & Total \\
\hline \multirow[b]{2}{*}{01} & $\mathrm{n}$ & 70 & 29 & 36 & 44 & 25 & 204 \\
\hline & $\%$ & $34.3 \%$ & $14.2 \%$ & $17.6 \%$ & $21.6 \%$ & $12.3 \%$ & $100.0 \%$ \\
\hline \multirow[b]{2}{*}{02} & $\mathrm{n}$ & 54 & 28 & 47 & 46 & 29 & 204 \\
\hline & $\%$ & $26.5 \%$ & $13.7 \%$ & $23.0 \%$ & $22.5 \%$ & $14.2 \%$ & $100.0 \%$ \\
\hline & $\mathrm{n}$ & 65 & 31 & 48 & 41 & 19 & 204 \\
\hline 03 & $\%$ & $31.9 \%$ & $15.2 \%$ & $23.5 \%$ & $20.1 \%$ & $9.3 \%$ & $100.0 \%$ \\
\hline
\end{tabular}

On item 01, which stated, "MOE may require to use E-learning after the health crisis" a majority (48.5\%) either disagreed or strongly disagreed with the statement, while one-third (33.9\%) either agreed or strongly agreed with it and (17.6\%) indicating neutrality.

On item 02, which stated, "I believe MOE strategy to encourage Elearning" majority (40.2\%) either disagreed or strongly disagreed with the statement, while third number $(36.7 \%)$ either agreed or strongly agreed with it and only $(23.0 \%)$ indicating neutrality.

On item 03, which stated, "The use of E-learning follows MOE strategy" more than one-third of the participants $(37.1 \%)$ either disagreed or strongly disagreed with the statement, while (29.4\%) either agreed or strongly agreed with it, while less than one-fourth $(23.5 \%)$ indicating neutrality.

\subsubsection{Perception of E-learning System}

The results of the descriptive statistics to each item of the Perception of E-learning system are presented in Table 6.

Table 6: Frequencies and Distributions of Respondents on Perception of E-learning system

\begin{tabular}{|c|c|c|c|c|c|c|c|}
\hline \multicolumn{2}{|c|}{ Item } & SD & D & $\mathrm{N}$ & A & SA & Total \\
\hline \multirow[b]{2}{*}{01} & $\mathrm{n}$ & 58 & 48 & 35 & 38 & 25 & 204 \\
\hline & $\%$ & $28.4 \%$ & $23.5 \%$ & $17.2 \%$ & $18.6 \%$ & $12.3 \%$ & $100.0 \%$ \\
\hline \multirow[b]{2}{*}{02} & $\mathrm{n}$ & 47 & 39 & 39 & 53 & 26 & 204 \\
\hline & $\%$ & $23.0 \%$ & $19.1 \%$ & $19.1 \%$ & $26.0 \%$ & $12.7 \%$ & $100.0 \%$ \\
\hline & $\mathrm{n}$ & 64 & 47 & 32 & 35 & 26 & 204 \\
\hline 03 & $\%$ & $31.4 \%$ & $23.0 \%$ & $15.7 \%$ & $17.2 \%$ & $12.7 \%$ & $100.0 \%$ \\
\hline
\end{tabular}


On item 01, which stated, "E-learning makes my work enjoyable" more than half $(51.9 \%)$ either disagreed or strongly disagreed with the statement, while less than one-third (30.9\%) either agreed or strongly agreed with it and (17.2\%) indicating neutrality.

On item 02, which stated, "E-learning is beneficial" a majority (42.1\%) either disagreed or strongly disagreed with the statement, while more than one-third (38.7\%) either agreed or strongly agreed with it and (19.1\%) indicating neutrality.

On item 03, which stated, "E-learning makes work noticeable" more than half of the participants (54.4\%) either disagreed or strongly disagreed with the statement, while less than one-third (29.9\%) either agreed or strongly agreed with it and less than one-sixth (12.2\%) indicating neutrality.

\subsubsection{Perception of Usefulness}

The results of descriptive statistics to each item of the Perception of Usefulness are presented in Table 7.

On item 01, which stated, "E- learning improves my work performance" a majority (45.1\%) disagreed or strongly disagreed with the statement, while a $(34.3 \%)$ indicated that they either agreed or strongly agreed with it, while (20.6\%) indicating neutrality. Since more participants strongly disagreed or disagreed. In general the statement was not favoured by the participants.

On item 02, which stated, "E-learning improve my work effectiveness" a majority (48.0\%) disagreed or strongly disagreed with the statement, while (33.3\%) either agreed or strongly agreed with it, with less than one-fifth (18.6\%) indicating neutrality, the statement was not generally in favour by the participants.

On item 03, which stated, "E-learning improve my work productivity" a majority (51.0\%) either disagreed or strongly disagreed with the statement, while less than one-third (29.4\%) either agreed or strongly agreed with it, while only (19.6\%) indicating neutrality.

Table 7: Frequencies and Distributions of Respondents on Perception of Usefulness

\begin{tabular}{|c|c|c|c|c|c|c|c|}
\hline \multicolumn{2}{|c|}{ Item } & SD & D & $\mathrm{N}$ & A & SA & Total \\
\hline \multirow[b]{2}{*}{01} & $\mathrm{n}$ & 55 & 37 & 42 & 46 & 24 & 204 \\
\hline & $\%$ & $27.0 \%$ & $18.1 \%$ & $20.6 \%$ & $22.5 \%$ & $11.8 \%$ & $100.0 \%$ \\
\hline \multirow[b]{2}{*}{02} & $\mathrm{n}$ & 61 & 37 & 38 & 39 & 29 & 204 \\
\hline & $\%$ & $29.9 \%$ & $18.1 \%$ & $18.6 \%$ & $19.1 \%$ & $14.2 \%$ & $100.0 \%$ \\
\hline \multirow[b]{2}{*}{03} & $\mathrm{n}$ & 62 & 42 & 40 & 32 & 28 & 204 \\
\hline & $\%$ & $30.4 \%$ & $20.6 \%$ & $19.6 \%$ & $15.7 \%$ & $13.7 \%$ & $100.0 \%$ \\
\hline
\end{tabular}




\subsubsection{Perception of Ease of Use}

The results of descriptive statistics to each item of Perception of Ease of Use are presented in table 8.

On item 01, which stated, "E-learning system clear and understandable" a majority (44.1\%) disagreed or strongly disagreed with the statement, while a $(37.8 \%)$ indicated that they either agreed or strongly agreed with it, while less than one-fifth (18.1\%) indicating neutrality. Since more number strongly disagreed or disagreed, the statement was not generally in favour by the participants.

On item 02 , which stated, "E-learning system and flexible" majority (43.1\%) disagreed or strongly disagreed with the statement, while (34.8\%) either agreed or strongly agreed with it, with less than one-fourth $(21.1 \%)$ indicating neutrality, the statement was not generally in favour by the participants.

On item 03, which stated, "E-learning system is easy" a majority $(42.6 \%)$ either disagreed or strongly disagreed with the statement, while more than one-third (38.2\%) either agreed or strongly agreed with it and $(19.1 \%)$ indicating neutrality. internet.

Table 8: Frequencies and Distributions of Respondents on Perception of Ease of Use

\begin{tabular}{|c|c|c|c|c|c|c|c|}
\hline \multicolumn{2}{|c|}{ Item } & SD & D & $\mathrm{N}$ & A & SA & Total \\
\hline \multirow[b]{2}{*}{01} & $\mathrm{n}$ & 48 & 42 & 37 & 53 & 24 & 204 \\
\hline & $\%$ & $23.5 \%$ & $20.6 \%$ & $18.1 \%$ & $26.0 \%$ & $11.8 \%$ & $100.0 \%$ \\
\hline \multirow[b]{2}{*}{02} & $\mathrm{n}$ & 51 & 39 & 43 & 51 & 20 & 204 \\
\hline & $\%$ & $25.0 \%$ & $19.1 \%$ & $21.1 \%$ & $25.0 \%$ & $9.8 \%$ & $100.0 \%$ \\
\hline & $\mathrm{n}$ & 46 & 41 & 39 & 57 & 21 & 204 \\
\hline 03 & $\%$ & $22.5 \%$ & $20.1 \%$ & $19.1 \%$ & $27.9 \%$ & $10.3 \%$ & $100.0 \%$ \\
\hline
\end{tabular}

\section{Conclusion:}

The goal of this research is to investigate the impact of e-learning on Kindergarten administrative staff and teachers; this study has found that the majority of participants on computer self-efficacy agreed that they would be able to use the E-learning system if they had some help beforehand, or If they had used a similar system before or if they had an instruction manual to aid them. Through the collected data, it can be asserted that there is no clear or direct correlation between the extent of job training and an improved learning environment. The participants were not in favor of the possible Ministry of Education strategic objective to keep implementing e-learning even after the COVID-19 crisis has ended. The members of staff stated that they were not happy with the technical support provided by the MOE; also 
the lack of technical support played a negative effect on the staff's productivity.

The participants disagreed with the usefulness of e-learning as they stated that it did not improve their work performance and effectiveness. The participants also said that they found the system not easy to use. They said that the system was neither clear, nor understandable or flexible.

However, Kuwait's Ministry of Education should invest more in reflecting a clear strategic objective behind e-learning implementation and roll-out such intention among school staffs effectively in order to ensure full utilization of the system in serving their educational purpose. In addition, MOE requires focusing on providing the required level of training to ensure system users' full utilization of the opportunity e-learning can provide to improve education, as well as elevate users' positive prospective toward elearning and their intention to use it.

\section{References:}

Alkharang, M. \& Ghinea, G., 2013. E-learning in Higher Educational Institutions in Kuwait: Experiences and Challenges. (IJACSA) International Journal of Advanced Computer Science and Applications, Vol. 4, No.4, 2013 4(4), pp. 1-6.

Al-Senaidi, S., Lin, L. \& Poirot, J., 2009. Barriers to adopting technology for teaching and learning in Oman. Computers \& Education, pp. 53(3), 575590.

Andoh, B., 2012. An Exploration of Teachers' Skills, Perceptions and Practices of ICT in teaching and Learning in the Ghanaian Second-Cycle Schools. Contemporary Education Technology, 3(1), pp. 36-49.

Bates, A. W., 2008. E-learning and distance education resources. [Online] Available at: http://www.tonybates.ca/2008/07/07/what-is-e-learning/ [Accessed 06 January 2021].

Bandura, A. \& Wood, R., 1989. Effect of Perceived Controllability and Performance Standards on Self-Regulation of Complex Decision Making. Journal of Personality and Social Psychology, Vol. 56(No. 5), pp. 805-814.

Business_Dictionary, 2016. Businessdictionary.com. [Online] Available at: http://www.businessdictionary.com/definition/policy.html

[Accessed February 2021].

Ching, C. C. \& Hursh, A. W., 2014. Peer modeling and innovation adoption among teachers in online professional development. Computers \& Education, Issue doi: 10.1016/j.compedu.2013.12.011, pp. 73, 72-82..

Compeau, D. R. \& Higgins, C. A., 1995. Computer Self-Efficacy: Development of a Measure and Initial Test. MIS Quarterly, 19(2), pp. 189211. 
Davis, F. D., 1986. A Technology Acceptance Model for Empirically Testing New End-User Information Systems: Theory and Results, s.l.: Massachusetts Institute of Technology

Dede, C. \& Ketelhut, J., 2009. A Research Agenda for Online Teacher Professional Development. Journal of Teacher Education, pp. 60(1), 8.

Ferdousi, B. J. A., 2009. study of factors that affect instructors' intention to use e-learning systems in two-year colleges. Nova Southeastern University. [Online] Available at: http://faculty.mu.edu.sa/public/uploads/1357292294.9264out26.pdf [Accessed January 2021].

Glueck, W., 1980. Business Policy and Strategy Management. 3rd ed. New York, NY: McGraw-Hill.

Gong, M., Xu, Y. \& Yu, Y., 2004. An Enhanced Technology Acceptance Model for WebBased Learning. Journal of Information Systems Education.

Greer, R. D., 2002. Designing teaching strategies: An applied behavior analysis systems approach. San Diego, CA: Academic Press.

Kopcha, T. J., 2012. Teachers' perceptions of the barriers to technology integration and practices with technology under situated professional development, s.l.: Computer \& Education.

Mintzberg, H., 1987. Strategy Concept I: Five Ps for Strategy. [Online] Available at: https://www.nmbu.no/download/file/fid/15125 [Accessed February 2021].

Ngai, E. W. T., Poon, L. K. J. \& Chan, Y. H. C., 2007. Empirical examination of the adoption of Web CT using TAM. Computers \& Education, pp. 48, 252-267.

Ralph, W., 1991. Help! The art of computer technical support. California: Peachpit Press.

Rowan, C. 2017. The Impact of Technology on the Developing Child. Huffpost. Available at: https://www.huffpost.com/entry/technology-childrennegative-impact_b_3343245 [Accessed February 2021].

Titthasiri, W., 2014. A Strategic Decision-Making Framework For ELearning System: Based on Strategic Planning Process and ISO 9126 Model, s.1.: International journal of engineering sciences \& research technology.

Van der wende, M. \& Van de ven, M., 2003. The Use of ICT in Higher Education. Utrecht: Lemma Publishers.

Waheed, M. \& Farooq Hussain, M., 2010. Empirical Study of Learner Contentment Towards E-Learning: Influential Role of Key Factors. [Online] Available at: http://linc.mit.edu/linc2010/proceedings/session11Waheed.pdf [Accessed January 2021]. 
